\title{
MEMÓRIAS ESGARÇADAS, ESPAÇOS VAZIOS, SUJEITOS DIASPÓRICOS: REFLEXÕES SOBRE PONCIÁ VICÊNCIO, DE CONCEIÇÃO EVARISTO
}

Angélica Maria Santana Batista

Resumo: Conceição Evaristo é uma escritora negro-brasileira que se destaca por ter uma escrita perpassada pela confrontação de categorias como cor, etnia, gênero e identidade. Na e pela articulação dessas categorias, representações ficcionais de um mundo possível diaspórico adquirem contornos e geram um campo interdiscursivo em que personagens negras subalternas inserem-se em espaços e vivências diferenciados. Ponciá Vicêncio (2003) é uma narrativa que retoma o passado da personagem-título em confrontação com um presente desesperançoso. Esse processo de ressignificação está em paralelo com os diferentes espaços em que ela vive. A partir da análise dos processos compositivos da personagem, é possível refletir que a invisibilidade desta está ligada à formação simbólica, social e psicológica da comunidade negra no Brasil.

Palavras-chave: Conceição Evaristo. Diáspora. Personagem. Memória.

Resumen: Conceição Evaristo es una escritora afrobrasileña que se destaca por haber escrito a través del enfrentamiento de categorías como el color, la etnia, el género y la identidad. En y a través de la articulación de estas categorías, las representaciones ficcionales de un posible mundo diaspórico adquieren contornos y generan un campo interdiscursivo en el que personajes negros subalternos se insertan en diferentes espacios y experiencias. Ponciá Vicêncio (2003) es una narrativa que retoma el pasado del personaje principal en confrontación con un presente desesperado. Este proceso de reencuadre es paralelo a los diferentes espacios en los que vive. A partir del análisis de los procesos compositivos del personaje, es posible reflejar que la invisibilidad del personaje está ligada a la formación simbólica, social y psicológica de la comunidad negra en Brasil.

Palabras llave: Conceição Evaristo. Diáspora. Personaje. Memoria. 
Conceição Evaristo (1946 - ) - poeta, contista, romancista, ensaísta, intelectual mineira - é doutora em Literatura Comparada pela Universidade Federal Fluminense (2011) e estuda, em paralelo à sua vida de escritora, as relações entre a literatura brasileira e as literaturas africanas de língua portuguesa. Participante ativa dos movimentos de valorização da cultura negra no país, estreou na literatura em 1990, quando passou a publicar seus contos e poemas na série Cadernos Negros, do grupo paulistano Quilombhoje Literatura. Escreveu obras como Ponciá Vicêncio (2003); Becos da memória (2006); Poemas da recordação e outros movimentos (2008); Insubmissas lágrimas de mulheres (2011), Olhos d'agua (2014) e Histórias de leves enganos e parecenças (2016), além de artigos variados em revistas e sites especializados.

A escritora negro-brasileira Conceição Evaristo possui obras que trabalham para além da sexualidade, da miséria e da ignorância experienciadas por ela mesma, retomando suas vivências de mulher negra. A figuração de suas personagens envolve a luta pela preservação da memória, presente na realidade de culturas marginalizadas. A escritora plasma vivências que relativizam o discurso hegemônico e manifestam a voz e o lugar de personagens femininas abafadas e subjugadas pelos centros de poder. 
Desse modo, sua narrativa é singular pela composição de personagens negras que estão para além de uma figuração decalcada em uma construção social e imagética em que os negros não sejam protagonistas de suas histórias e vontades. Por meio da representação de espaços ignorados da sociedade, ela consegue fazer o leitor acessar perspectivas até então pouco exploradas de forma contundente pela literatura canônica que, mesmo tendo a presença de personagens negras, muitas vezes não conseguiu abarcar suas subjetividades. Para Maria Aparecida Andrade Salgueiro,

Conceição Evaristo se destaca hoje, junto a nomes como os de Geni Guimarães, Miriam Alves, Sonia Fátima da Conceição e outras, como representante de um movimento feminino com expressão literária que, aqui como nos Estados Unidos - só que com características próprias, locais, é claro busca resgatar nomes esquecidos pela História literária e instigar o aparecimento de outros, assim como a expressão de emoções há mais de séculos recalcadas, caladas e oprimidas. (2004, p. 120-127)

Esse resgate se fundamenta na revisão da cultura e, consequentemente, da própria literatura brasileira, visto que a cultura popular de base africana sempre foi objeto de preconceito e, assim, processos de apropriação 
cultural ou mesmo aculturação foram uma constante na construção da identidade literária nacional. Desse modo, a concepção de uma escrita negro-brasileira é aqui vista como consciência de que o fazer literário é perpassado por várias questões que exigem ser revisadas e discutidas, por meio de enfrentamento, em todos os espaços instituídos e/ ou construídos.

A necessidade de identificação de uma classe negra, que exige se enxergar nos diversos espaços da sociedade brasileira, é um dos fatores que tem dado maior visibilidade à literatura negro-brasileira ${ }^{1}$. Diferenciada, a literatura negrobrasileira nunca será "panfletagem" das agruras sofridas pelos negros, mas a necessidade de se abarcar novos sujeitos e subjetividades que não necessariamente instituam um novo cânone, mas que manifestem um imaginário plural da sociedade brasileira.

No sistema literário como um todo, a formação dos escritores e a identificação do público-alvo é de extrema importância. Sobre esse assunto, a escritora Ana Maria Gonçalves pontua, com propriedade, que:

1 O termo literatura negro-brasileira vem sendo defendido pelo escritor brasileiro Cuti e outros pesquisadores. A utilização dos conceitos negra ou afro-brasileira não abarcaria, na totalidade, a complexidade do que é ser um negro no Brasil. Aceitar e defender que há uma literatura negro-brasileira é visto não somente como uma questão estética, mas como a expressão das lutas e conquistas dos negros que foram escravizados e de seus descendentes. 
Precisamos formar mais escritoras e escritores que, a partir de experiências e formações distintas, insiram suas próprias histórias na construção desse imaginário que chamamos de Brasil. Desta maneira, um grande público leitor potencial poderia ser formado, pois passaria a se identificar também, ao se ver representado. Conseguindo se transportar para dentro da história, literatura vira prazer, uma grande fonte de sonhos e de universos reais e possíveis. Conhecimento e, principalmente, a sua produção, é poder. ${ }^{2}$

A literatura negro-brasileira, com destaque para a produzida após os anos 1970, devido a vários fatores sociais, culturais e econômicos, conquista espaços de poder e representa personagens figuradas para além dos estereótipos, ancorando-se em um lugar de enunciação no qual a alteridade é a tônica. Assim,

em essência, uma das coisas que tais grupos buscam, além da apresentação de uma voz até então pouco (ou não) ouvida, é a rediscussão das formas de estabelecimento do cânon literário. $\mathrm{Na}$ medida em que grupos se reorganizam dentro da sociedade, tal quadro é obviamente refletido pela produção cultural, e a literatura se posiciona sob a égide de um novo perfil. Grupos até então considerados sem produção literária começam a apresentá-la e, principalmente,

2 Entrevista disponível em: https://www.geledes.org.br/ana-maria-goncalves-fala-deleituras-escritas-e-producao-literaria-negra. Acesso em 22 fev. 2021. 
vêm a conhecimento produções anteriores suas até então desconhecidas ou julgadas inexistentes. (SALGUEIRO, 2004, p. 115)

Pensando especificamente em Conceição Evaristo, pode-se dizer que a experiência de ser mulher e negra no Brasil denota uma vivência que se revela em diferentes significações e perspectivas, pois experiências diversas produzem textos diversos na esfera do sensível e do simbólico, o que combina com as palavras de Miriam Alves, diferenciando escritoras negras e brancas. Diz ela:

Estas identidades que pode parecer, a espectadores apressados em conclusões, um cordão de isolamento entre as mulheres brancas e negras, é na verdade um chamado para a consciência da complexidade da divisão social do papel da Mulher. Ao assumir esta identidade literária, as afro-brasileiras ultrapassam o cordão de isolamento, colocam o bloco na Avenida Brasil da literatura. Rompe-se, neste ato, com a parcialidade que é falar de literatura feminina (ou escrita por mulheres) sem levar em conta a amplitude das vivências relatadas pelas afrodescendentes. Não se trata de mera divisão temática somente, mas de um chamado à revisão de conceitos, não só literários, mas de transformações da sociedade brasileira no cerne da mentalidade patriarcal subjacente, nascida claramente na instituição de um sistema escravocrata. (ALVES, 2010, p. 188) 
A obra literária e crítica de Conceição Evaristo é um exemplo emblemático da produção negro-feminina brasileira, ancorada em repensar espaços público e privado em que personagens negras transitam. Nesses espaços, elas experienciam diferentes opressões e violências e isso se espraia nos textos da escritora, já que:

A produção textual das mulheres negras é relevante, pois põe a descoberto muitos aspectos de nossa vivência e condição que não estão presentes nas definições dominantes de realidade e das pesquisas históricas. Partindo de um outro olhar, debatendo-se contra as amarras ideológicas e as imposições históricas, propicia uma reflexão revelando a face de um BrasilAfro (destaque no original) feminino, diferente do que se padronizou, humanizando esta mulher negra, imprimindo um rosto, um corpo e um sentir mulher com características próprias. (ALVES, 2010, p. 67)

A narrativa Ponciá Vicêncio possui este viés, visto que humaniza uma mulher negra aparentemente comum, mas com uma profundidade psicológica ímpar, imersa em "um vazio que era só dela" (EVARISTO, 2003, p. 66). É uma narrativa fragmentada com forte teor conotativo, e apresenta processos compositivos complexos. A personagem-título revela-se a partir de reminiscências e vazios que se encontram no choque de diferentes espaços, temporalidades e vozes. 
Ponciá se apresenta como ser alheado, ensimesmado. Esse alheamento inicia com o próprio nome, não compreendido por ela, e só piora no decorrer da narrativa:

O tempo passava, a menina crescia e não se acostumava com o próprio nome. Continuava achando o nome vazio, distante. Quando aprendeu a ler e a escrever, foi pior ainda, ao descobrir o acento agudo de Ponciá. Às vezes, num exercício de autoflagelo ficava a copiar o nome e a repeti-lo, na tentativa de se achar, de encontrar seu eco. (EVARISTO, 2003, p. 29)

A falta de eco de "um nome que não tinha dono" (EVARISTO, 2003, p. 29) era acentuada pelo fato de Vicêncio ser o sobrenome de um coronel (senhor das terras da vila onde Ponciá cresceu) fazendo com que todos os negros da localidade se chamassem Vicêncio, mantendo "a marca daqueles que se fizeram donos das terras e dos homens" (EVARISTO, 2003, p. 29). Esse processo de identificação com o passado escravocrata denota o teor diaspórico da narrativa, lembrando que a Diáspora africana possui suas idiossincrasias, já que:

Do mesmo modo, o conceito diáspora passou a ser utilizado por religiosos, ativistas e intelectuais ligados às tradições africanas e à luta antirracista. Assim, também como os judeus, os descendentes de africanos espalharam-se pelo mundo. Contudo, a 
marcante diferença encontra-se no fato de que estes o fizeram, sobretudo, de modo compulsório e como resultado da escravidão. Uma vez instalados em quaisquer dos continentes, por mais que as tradições fossem represadas ou aniquiladas, os descendentes de africanos davam início a um processo de criação, invenção e re-criação da memória cultural dos laços mínimos de identidade, cooperação e solidariedade. Com esta rede de interação, as múltiplas culturas africanas, que se espalharam pelo mundo, preservaram visíveis traços das inúmeras comunidades étnicas a que pertenciam, sendo os mais marcantes aqueles manifestos por meio da força do ritmo musical, dos movimentos assimétricos na dança, na culinária e nas sabedorias de cura extraídas da fauna e da flora tropical. (TAVARES, 2008/2010, p. 81)

A tentativa de identificação com a comunidade negra se acentua com o constante deslocamento de Ponciá em busca de suas origens e das trocas existentes entre ela e a mãe, constituindo um cenário feminino. Para Eduardo de Assis Duarte:

O texto de Ponciá Vicêncio destaca-se também pelo território feminino de onde emana um olhar outro e uma discursividade específica. É desse lugar marcado, sim, pela etnicidade que provém a voz e as vozesecos das correntes arrastadas. Vê-se que no romance fala um sujeito étnico, com as marcas da exclusão inscritas na pele, a percorrer nosso passado em contraponto 
com a história dos vencedores e seus mitos de cordialidade e democracia racial. Mas, também, fala um sujeito gendrado, tocado pela condição de ser mulher e negra num país que faz dela vítima de olhares e ofensas nascidas do preconceito. Esse ser construído pelas relações de gênero se inscreve de forma indelével no romance de Conceição Evaristo, que, sem descartar a necessidade histórica do testemunho, supera-o para torná-lo perene na ficção. (2006, p. 308)

Considerado um romance de formação ${ }^{3}$, o texto evaristiano possui particularidades oriundas do próprio fazer literário da autora, que busca revelar as agruras dos negros em busca de suas origens e identidades, o que imprimiria ao texto um mundo possível diaspórico, visto que, de acordo com Stuart Hall, as comunidades diaspóricas vivem a ferida do desenraizamento, pois "longe de constituir uma continuidade com os nossos passados, nossa relação com essa história está marcada pelas rupturas mais aterradoras, violentas e abruptas" (2018, p.33). Essa falta de continuidade perpassada por violências físicas e simbólicas é sentida por Ponciá, que se encontra em um vazio existencial quando se percebe imersa em um mundo

3 Aqui existe a apropriação e flexibilização do termo romance de formação, tradicionalmente visto como narrativa que " poderá ser chamada de Bildungsroman, sobretudo devido ao seu conteúdo, porque ela representa a formação do protagonista em seu início e trajetória em direção a um grau determinado de perfectibilidade; em segundo lugar, também porque ela promove a formação do leitor através dessa representação, de uma maneira mais ampla do que qualquer outro tipo de romance" (MORGENSTERN apud MAAS, 2000, p. 19). 
que a exclui por ser mulher e negra. Tanto no campo como na cidade, ela ocupa espaços periféricos que só reforçam seu não pertencimento. Para Eduardo Assis Duarte:

Em Ponciá Vicêncio, a autora retoma o procedimento - que arriscaríamos chamar de brutalismo poético - ao narrar numa linguagem concisa e densa de sentido a vida de uma afro-brasileira oriunda do mundo rural, desde a infância até a "maturidade" desterritorializada na favela em que vegeta junto ao companheiro. A narrativa configura-se, conforme dissemos, como um bildusgsroman feminino e negro ao dramatizar a busca quase intemporal da protagonista, a fim de recuperar e reconstituir família, memória, identidade. No entanto, a veia antropofágica se faz presente na postura de rasurar o modelo europeu para conformá-lo às peculiaridades da matéria representada. Assim, a apropriação feita por Conceição Evaristo ganha contornos paródicos, pois em lugar da trajetória ascendente do personagem em formação, oriunda de Goethe e tantos mais, o que se tem é um percurso de perdas materiais, familiares e culturais. E, em lugar da linearidade triunfante do herói romanesco, temos uma narrativa complexa e entrecortada, a mesclar de forma tensa passado e presente, recordação e devaneio. (DUARTE, 2006, p. 306-307)

A apropriação da estrutura de um romance tradicional em uma narrativa que trata da difícil identificação dos sujeitos 
diaspóricos revela as fronteiras em que as comunidades pós-coloniais se formaram em uma perspectiva subalterna. Isso exprime a corrosão do eurocentrismo em diferentes níveis semionarrativos, visto que as estratégias narrativas e a temática são construídas como antítese de um romance de formação europeu.

O fato de a narrativa ser protagonizada por uma mulher negra também é um fator instigante, já que, para Wilma Patrícia Marzardi Dinardo Mass, “o romance de formação ou de aprendizagem feminino mostrar-se-ia pois como um vetor revolucionário, subversivo, pela subversão do próprio modelo textual ao qual recorre" (2000, p. 247) e a visibilidade de questões étnico-raciais oferece uma matiz que demonstra a representação da procura pela identidade negro-brasileira.

O devaneio, a lembrança e a apatia denotam uma personagem esfacelada pela história incompleta de seus ancestrais. Sendo considerada herdeira de seu avô, cuja parecença era nítida para todos que o conheceram, não consegue fazer conexões com sua vivência e o passado e "assim como ele [o avó], gostava de olhar o vazio [...] sabia para onde estava olhando. Ela via tudo, via o próprio vazio" (EVARISTO, 2003, p. 29). Essa fixação pelo vazio percorre toda a narrativa, e a personagem transforma-se também em 
um vazio que precisa ser preenchido. Adulta, desfalecendo na favela, sem perspectivas ou alegrias, Ponciá mergulha em sensações e pensamentos esparsos na tentativa de se encontrar e se compor, já que não consegue encontrar traços de pertencimento no espaço da cidade. Assim,

ela gastava todo o tempo com o pensar, com o recordar. Relembrava a vida passada, pensava no presente, mas não sonhava com o futuro. O amanhã de Ponciá era feito de esquecimento. [...] Uma noite ela passou todo o tempo diante do espelho chamando por ela mesma. Chamava, chamava e não respondia. (EVARISTO,2003, p. 19)

A primeira imagem da protagonista adulta é em sua casa na favela, ora sentada na janela ora a se mirar com desespero no espelho. Seu barraco simboliza a sua luta na cidade, onde trabalhara por anos com o intuito de oferecer uma vida melhor para os seus. No entanto, no decorrer da narrativa, esse espaço é retratado de forma a mostrar a perda da tenacidade de Ponciá, com buracos nas paredes e nas telhas e com ratos a caminhar no chão, onde havia um fogão com poucas brasas entre cinzas, com a uma janela em que ficava "olhando o nada" (EVARISTO, 2003, p. 19) em um alheamento tamanho que até "esquecia de contemplar o céu" (2003, p. 14).

Esse espaço é um contraste com a sua casa na Vila Vicêncio, no tempo em que "gostava de ser menina. Gostava de ser ela 
própria. Gostava de tudo. Gostava." (EVARISTO, 2003, p. 13), perto do rio em que havia nascido e que encontrava material para fazer pratos de cerâmica. Sua casa no campo simboliza o território feminino, em que ela e sua mãe vivem a mexer no barro e esperar os homens voltarem da lida na terra dos brancos. Utilizando o olhar da mãe para configurar Ponciá, o narrador demonstra os momentos de troca e afeto entre mãe e filha:

A menina era a sua filha mulher. Falavam, trabalhavam e cantavam juntas. Já bem pequena, ela entendia o barro e ia ao rio buscar a massa. Sabia qual era a melhor, qual a mais macia, a mais obediente. Reconhecia aquela que aceitava de bom grado o comando das mãos, traduzindo em formas ou desejos de quem cria. Ela conhecia de olhos fechados a matéria do rio. (EVARISTO, 2003, p. 77)

Nascer, transitar e depois ansiar pelo rio, cujo "curso das águas é a corrente da vida e da morte" (CHEVALIER; GHEERBRANT, 2012, p. 780), exprime a formação de uma vida transfigurada por outras vidas e mortes. Ponciá Vicêncio é diferente porque o chamar do rio a transforma em um ser que retém e fecunda outras vivências dentro de si, o que se prenuncia no dia do nascimento da personagem:

Uma manhã, Maria Vicência acordou ouvindo choro de criança. Apurou os ouvidos. E na atenção da escuta, o susto. $\mathrm{O}$ 
choro vinha de dentro dela. Alisou a barriga acarinhando a filha que ali cumpria o tempo de ser, sentiu movimentos e soluços. O que fazer? [...] Caminhou intuitivamente para o rio e à medida que adentrava nas águas, a dor experimentada pela filha se fazia ouvir de uma maneira mais calma (EVARISTO, 2003, p. 124-125)

O rio é, desse modo, o espaço em que Ponciá se sente livre para brincar e produzir seus brinquedos. Além disso, é o único local em que tenta ver a si mesma, repetindo seu nome ao mesmo tempo que mira as águas. O interrogarse ao espelho, substituto do rio em que Ponciá crescera, é uma tentativa de ter seu nome ecoando dentro de si e, consequentemente, evocar uma identidade nunca encontrada. Não se pode deixar de salientar que a analogia água-espelho é muito profícua porque ambos podem ser usados para a especulação e para representar a alma de quem os contempla (CHEVALIER GHEERBRANT, 2012). Este último fator é relativizado na narrativa, visto que Ponciá nada consegue enxergar e "ela vazia se sentia sem nome" (EVARISTO, 2013, p. 19).

Essa interrogação constante se dá em seu desejo de ser mais que seu próprio nome e sua própria história, ambos pertencentes aos brancos. O rastreamento da identidade, expresso pelo choque de realidades, espaços e 
temporalidades, desenvolve-se na tentativa de erigir uma linha temporal afetiva a fim de amalgamar suas memórias e fracassos tecidos muito antes de seu nascimento.

A indagação sobre o seu nome é um ponto nevrálgico na construção da personagem. Ao não se identificar com ele, lança indagações sobre a sua própria história e a de seus ancestrais, fazendo com que o leitor comece a delinear a personagem sob o signo da confrontação. Procurando substitutos para o seu nome, no tempo em que ainda sonhava, Ponciá tenta emitir narrativas verdadeiras para as suas raízes. A composição de si mesma, além da revisão da trajetória de sua própria família, erigida sobre uma relação tensa de subalternidades questionadas, porém não totalmente superadas, é um desafio. Essa relação se coloca de maneira violenta na lembrança, conhecida e repetida por todos, do avô de Ponciá:

Vô Vicêncio com a mulher e os filhos viviam anos e anos nessa lida. Três ou quatro dos seus, nascidos do "ventre livre", entretanto, como muitos outros, tinham sido vendidos. Numa noite, o desespero venceu. Vô Vicêncio matou a mulher e tentou acabar com a própria vida. Armando com a mesma foice que lançara contra a mulher, começou a se autoflagelar decepando a mão. Acudido, é impedido de continuar o intento. Estava louco, chorando e rindo. Não morreu o Vô Vicêncio, a vida continuou 
com ele, independentemente de seu querer. Quiseram vendê-lo. Mas quem compraria um escravo louco e com o braço cotó? Tornou-se um estorvo para os senhores. Alimentava-se das sobras. Catava o resto dos cães, quando não era assistido po nenhum dos seus. Viveu ainda muitos e muitos anos. Assistiu, chorando e rindo, aos sofrimentos, aos tormentos de todos. E só quando acabou de rir todos os seus loucos risos e chorar todos os seus insanos prantos, foi que Vô Vicêncio se quedou calmo. (EVARISTO, 2003, p. 51-52)

A história do Vô Vicêncio é uma versão do sistema escravocrata brasileiro não levada em consideração pelo discurso oficial, o que também configura o discurso diaspórico. O desespero sentido por ele se desdobra em sua descendência e Ponciá, sua herdeira, mesmo adulta e vivendo na cidade como empregada doméstica, em uma visita à terra dos negros, escuta as histórias "como se fosse a primeira vez. Bebia os detalhes remendando cuidadosamente o tecido roto de um passado, como alguém que precisasse recuperar a primeira veste para nunca mais se sentir desamparadamente nua" (EVARISTO, 2003, p. 63). Essa escuta repetitiva se choca com o silêncio recorrente de suas ausências em um contínuo movimento de esquecimento e rememoração.

Essa confrontação com o passado escravocrata também é vislumbrada na caracterização do pai da protagonista, 
pouco lembrado por ela por estar sempre a lavrar as terras dos brancos:

Filho de ex-escravos, crescera na fazenda levando a mesma vida dos pais. Era pajem do sinhô-moço. Tinha a obrigação de brincar com ele. [...] Um dia, o coronelzinho exigiu que ele abrisse a boca, pois queria mijar dentro. O pajem abriu [...] naquela noite teve mais ódio do pai. Se eram livres, por que continuavam ali? Por que, então, tantos e tantas negras na senzala? [...] Perguntou e a resposta do pai foi uma gargalhada rouca de meio riso e meio pranto. $O$ homem não encarou o menino. Olhou o tempo como se buscasse no passado, no presente e no futuro uma resposta precisa, mas que estava a lhe fugir sempre. (EVARISTO, 2003, p. 18)

A vivência e a lembrança da escravidão acabam por ser uma experiência sensível que se reverbera na vida da protagonista, mostrando várias maneiras de se encarar a repressão imposta pelo sistema escravocrata ainda vigente. Ao contrário de Vô Vicêncio, que encontra no assassinato e na loucura um modo de suportar sua vida, o pai abafa suas perguntas, verga-se sobre o poderio dos brancos, silencia sua raiva e "se descontente estava, era resmungar, mas tão baixinho e com os lábios tão cerrados, que os resmungos caíam para si próprio, numa discordância funda e nula" (EVARISTO, 2003, p. 30). Esse silêncio da figura masculina que deveria 
ser a mais marcante de sua vida (mas que não está presente porque precisa enriquecer os brancos), em paralelo com a alienação de seu avô, reverberam na vida da protagonista em uma marca dolorosa que não a deixa progredir, pois o silêncio a obriga a retornar constantemente aos abismos do vivido e da memória em momentos em que "caía meio morta, desfalecida, vivendo, porém, o mundo ao redor, mas não se situando, não se sentindo" (EVARISTO, 2003, p. 63).

Isso se dá porque "um acontecimento vivido é finito, ou pelo menos encerrado na esfera do vivido, ao passo que um acontecimento lembrado é sem limites, porque é apenas uma chave para tudo o que veio antes e depois" (BENJAMIN apud BERND, 2018, p. 131). O não limite do lembrado faz com que Ponciá fique paralisada, em busca de um sentido que está no contato com as suas origens também nebulosas. Esse retorno constante e, aparentemente, infrutífero, faz com que as fronteiras entre o familiar e o simbólico sejam esgarçadas.

A perpetuação da condição de escravizados da família Vicêncio foi uma das razões de a personagem procurar uma nova vida. Cansada de tanta pobreza, resolve sair de casa repentinamente:

Estava cansada de tudo ali. De trabalhar o barro com a mãe, de ir e vir às terras dos brancos e voltar de mãos vazias. De ver a 
terra dos negros coberta de plantações, cuidadas pelas mulheres e crianças, pois os homens gastavam a vida trabalhando na terra dos senhores, e depois a maior parte das colheitas ser entregue aos coronéis. Cansada da luta insana, sem glória, a que todos se entregavam para amanhecer cada dia mais pobres, enquanto alguns conseguiam enriquecer-se todo o dia. (EVARISTO, 2003, p. 33)

No entanto, embora fora da roça, longe da fazenda dos brancos, Ponciá não consegue romper com seu papel de subalterna, porém encontra-se feliz por ter feito algo a mais que muitos dos que viviam no povoado. Doméstica a vida toda, suas vitórias são conseguir um barraco na favela e ter um companheiro. Logo no início da relação, o seu homem a encara como uma mulher tenaz com muitos sonhos e certezas:

Ele estava enamorado e observara que ela era uma pessoa muito ativa. Estava sempre a lidar. Era bonita. Tinha um jeito estranho que ele não sabia bem o que era. Gostava de cantar. Tinha uma voz de ninar criança e de deixar homem feliz. Haviam conversado algumas vezes. Sabia que a moça viera da roça e que deixando a mãe e o irmão, pessoas que agora ele procurava tanto. Trabalhava ali e tinha uma casinha no morro. Ele gostava da tenacidade dela, de seu olhar adiante. Era uma mulher sozinha e muito mais forte do que ele. Era de uma pessoa assim que ele precisava. Ele estava também 
a trabalhar, só que sozinho e não conseguia nem sonhar. Ela, entretanto, figurava ser a dona dos sonhos, parecia morar em outro lugar. (EVARISTO, 2003, p. 65)

No entanto, isso logo é relativizado e a cidade se constrói como um espaço que oprime e aliena. Mesmo que no início haja uma certa esperança de uma vida melhor, Poncá Vicêncio não deixa de ser anulada só porque não estava mais no campo. Ao comprar seu barraco na favela, ela assume mais uma vez um espaço periférico, agora dentro da ordenação citadina.

Desse modo, Ponciá se torna duplamente excluída. Seja no povoado, seja na cidade, ela não conquistou um lugar de fala, visto que ocupava espaços periféricos e marginalizados. A invisibilidade de Ponciá no campo e na cidade é reflexo do próprio processo de invisibilidade dos espaços ocupados pelos negros.

Essa divisão racial do espaço fragmenta ainda mais a personagem duplamente periférica. No campo, pelo menos, ela se identificava com sua família. Na cidade, não tinha ninguém. Essa falta de identificação faz com que ela perca o contato com a terra e com ela mesma. A constatação de que perderia para a cidade é paulatinamente construída como uma consequência natural da ausência dos seus, 
expressa pelas mãos que não paravam de coçar e pelos seus constantes devaneios:

A mão continuava coçando e sangrando entre os dedos, nesses momentos ela sentia uma saudade de trabalhar com o barro. Havia dias, também, que o vazio que the enchia a cabeça vinha por duas ou três vezes. Se estivesse de pé, agarrava com força na beira da pia ou do tanque e esperava a sensação passar. Nem sempre passava rápido. Tinha muito medo de que a patroa visse. (EVARISTO, 2003, p. 81)

Após algum tempo, sem notícias do irmão e da mãe, Ponciá Vicêncio não suporta mais viver na cidade e o processo de dissociação se fortalece. Com o passar dos anos, e se indaga: "o que acontecera com os sonhos tão certos de uma vida melhor? Não eram somente sonhos, eram certezas! Certezas que haviam sido esvaziadas no momento em que perdera contato com os seus. E agora feito morta-viva, vivia" (EVARISTO, 2003, p. 34). Essa morte em vida é expressa pela falta de laços de Ponciá. Sem a família por perto, perde a sua frágil identidade, já que não consegue se identificar com a cidade e com seu companheiro, cujo amor morrera junto com seus filhos, o que combina com suas indagações sobre seu casamento:

Ele, ao lado dela, ressonava tranquilo, como se estivesse com a vida resolvida. Deus meu, 
será que o homem não desejava mais nada? Para ele bastava o barraco, a comida posta na lata de goiabada vazia? O pó, a poeira das construções civis, os goles de cachaça toda a semana? 0 papo rápido com os amigos? Será que isso bastava? Às vezes, ela percebia nele um vislumbre de tristeza. Tinha vontade então de abrir o peito, de soltar a fala, mas o homem era tão bruto, tão calado. Nem quando ela o conheceu, nem quando ela e ele sorriam e se amavam ainda, Ponciá conseguiu abrir para ele algo além do que seu corpo-pernas. (EVARISTO, 2003, p. 44)

Ponciá não encontra alento na maternidade. Sem filhos para perpetuar suas histórias e memórias, perde-se no mundo dos sonhos, em um constante recordar que aumenta seu vazio. A morte das crianças aumenta a distância entre a personagem principal e o marido:

Lembrou-se dos sete filhos que tivera, todos mortos. Alguns viveram por um dia. Ela não sabia bem por que eles haviam morrido. Os cinco primeiros tivera em casa com a parteira Maria da Luz. A mulher chorava com ela a perda dos bebês, tão sacudidinhos, mas que não vingavam nunca. Os dois últimos tivera no hospital. Os médicos disseram que eles morriam por causa de uma complicação de sangue. Depois dos sete, ela nunca mais engravidou. $\mathrm{O}$ homem de Ponciá Vicêncio se mostrava também acabrunhado com a perda dos meninos. A cada gravidez sem sucesso, ele bebia por longo tempo e evitava contato com ela. Depois voltava, dizendo que iria 
fazer outro filho e que aquele haveria de nascer, crescer e virar homem. Ponciá já andava meio desolada. Abria as pernas, abdicando do prazer e desesperançosa de ver se salvar o filho. (EVARISTO, 2003, p. 53)

Os filhos mortos exteriorizam o não lugar de Ponciá Vicêncio, obrigando-a questionar o lugar nos negros no mundo, aparentemente fadados a trabalhar sem nenhum prazer. A morte em vida de Ponciá se desdobra em mortes em vida de todos os seus ancestrais e os filhos não vingados parecem prenunciar o fim dessa corrente sem sonhos e felicidade:

Os pais, os avós, os bisavós sempre trabalhando na terra dos senhores. A cana, o café, toda a lavoura, o gado, as terras, tudo tinha dono, os brancos. Os negros eram donos da miséria, da fome, do sofrimento, da revolta suicida. Alguns saíam da roça, fugiam para a cidade, com a vida a se fartar de miséria, e com o coração a sobrar esperança. Ela mesma havia chegado à cidade com o coração crene em sucessos e eis no que deu. Um barraco no morro. Um ir e vir para a casa das patroas. Umas sobras de roupa e de alimento para compensar um salário que não bastava. Um homem sisudo, cansado, mais do que ela talvez, e desesperançado de outra forma de vida. Foi bom os filhos terem morrido. Nascer, crescer, viver para quê? (EVARISTO, 2003, p. 82)

A falta de filhos e as ausências são recebidas pelo marido de forma violenta, o que mostra mais um contraste entre a 
casa do campo e da cidade, entre o passado quase idílico da infância e o presente opressor da vida adulta. Enquanto no campo os objetos provinham do rio e eram cuidadosamente guardados, além de o pai e o irmão fazerem tudo o que a mãe Maria Vicêncio mandava, na cidade a protagonista possuía um prato de goiabada para comer e o marido a espancava dizendo que ela estava com um encosto quando a via jogada em um cantinho do barraco, como aqui retratado:

Houve época em que ele bateu, esbofeteou, gritou... às vezes, ela se levantava e ia arrumar a comida, outras vezes, não. Um dia ele chegou cansado, a garganta ardendo por um gole de pinga e sem um centavo para realizar tão pouco desejo. Quando viu Ponciá parada, alheia, morta-viva, longe de tudo, precisou fazê-la doer também e começou a agredi-la. Batia-lhe, chutava-a, puxava-Ihe os cabelos. Quando o homem viu o sangue a escorrer-lhe pela boca e pelas narinas, pensou em matá-la, mas caiu em si assustado. Foi ao pote, buscou uma caneca d'agua e limpou arrependido e carinhoso o rosto da mulher [...] Ele ficou com o remorso guardado no peito. A mulher devia estar doente, devia estar com algum encosto. (EVARISTO, 2003, p. 96-97)

Com o tempo, porém, o marido de Ponciá demonstra pela primeira vez o compreendimento da companheira. O que havia nela não era um encosto, mas uma solidão latente, uma falta de raízes e perspectivas. Estar afastada 
do rio e de sua herança estava destruindo seus sonhos. Ponciá Vicêncio estava incompleta e não poderia então dar-se mais ao homem. Este, por outro lado, finalmente também percebe que não pode oferecer àquela relação nada além do corpo (algo que ela intuíra desde o início da relação). A falta de ponte entre o casal isola mais ainda a mulher e ele, tomado de ternura, tenta apenas vê-la como uma companheira de sofrimento.

Os constantes deslocamentos de Ponciá demonstram uma tentativa, mesmo que frustrada, de procurar novos começos, construir novos significados. Ao trilhar os caminhos na linha do trem, ela encontra um mundo fragmentado que a exclui, o que a obriga a ressignificar o seu lugar em sua terra natal. A jornada da protagonista entre a vila e a cidade, entre o quarto de empregada e a favela, entre o vivido e o lembrado na verdade faz com que ela estremeça uma estrutura em que todos os seus estavam "sob o jugo de um poder que, como Deus, se fazia eterno" (EVARISTO, 2003, p. 49), o que combina com a simbologia do trem, posto que este "evoca o veículo da evolução, que dificilmente tomamos, na direção certa ou errada, ou que perdemos; simboliza uma evolução psíquica, uma tomada de consciência que prepara a uma nova vida" (CHEVALIER; GHEERBRANT, 2012, p. 897). 
Desse modo, nada mais justo que terminar a narrativa reencontrando sua mãe e irmão na estação de trem, demonstrando mais uma vez que a retomada do rio e a volta a seu lugar de origem não poderia ser mais adiada. No encontro, a mãe percebe:

A menina continuava bela; no rosto sofrente, feições de mulher. Por alguns momentos, em outras faces, não só a de Vô Vicêncio, visitaram o rosto de Ponciá. A mãe reconheceu todas, mesmo aquelas que chegavam de um outro tempo-espaço. Lá estava a sua menina única e múltipla. Maria Vicêncio se alegrou, o tempo de reconduzir a filha à casa, à beira do rio estava acontecendo. Ponciá voltaria ao lugar das águas e lá encontraria a sustância, o húmus para o seu viver. (EVARISTO, 2003, p. 125)

Ao retornar ao rio, agora modificada pela aceitação de seu tempo lembrado e esquecido, Ponciá Vicêncio constitui o "elo e herança de uma memória reencontrada pelos seus, não se perderia jamais, se guardaria nas águas do rio" (EVARISTO, 2003, p. 128). Assim, o conjunto de experiências da personagem título se mostra como a apropriação dos territórios e das memórias, além de tecer elos de significação definidos por sua relação com o espaço e o tempo em um processo identitário ancorado em uma memória coletiva que se coloca nas fronteiras unidas em um constante diálogo. Os 
processos de composição da personagem demonstram um mundo possível ficcional em que a coexistência de discursos vários explicitam a apreensão da experiência diaspórica.

A reconstituição das diversas histórias e memórias dos negros do Brasil na obra de Conceição e de outros escritores simboliza a emergência de imagens que contrariam o que é comumente chamado de cânone literário, formado por forças diversas que, quando vistas abstratamente sob uma perspectiva diacrônica ou sincrônica, podem se transformar em vetores legitimadores de algumas tendências afins em dada época. Na obra de Conceição Evaristo, há uma espécie de releitura da história pelo olhar dos marginalizados, em especial das mulheres negras, em uma busca identitária. Segundo Jacques Le Goff, "a ausência de um passado conhecido e reconhecido, à míngua de um passado, pode também ser fonte de grandes problemas de mentalidade ou identidade coletivas" (1992, p. 204). Mulheres negras, as personagens de Conceição precisam trocar impressões como uma maneira de reconhecimento de si mesmas. As questões que elas levantam são também fruto da polivalência histórica contemporânea, que demonstra o desmoronamento ou flexibilização de ideologias e de discursos: cultura, identidade, subjetividade e gênero. São ficcionalizações entre as rachaduras da história, formando 
novas versões e novos significados, textos múltiplos com olhar particularizado, visto que

o sentido e a forma não estão nos
acontecimentos, mas nos sistemas que
transformam esses acontecimentos
passados em "fatos" históricos e
presentes. Isso não é um "desonesto
refúgio para escapar à verdade", mas um
reconhecimento da função de produção
de sentido dos construtos humanos.
(HUTCHEON, 1991, p. 122)

Ponciá Vicêncio, portanto, pode ser lida como uma narrativa que evidencia o discurso diaspórico e relativiza a história única, em uma jornada simbólica de uma personagem que se constitui como sujeito a partir da confrontação de memórias e espaços. Ao refletir sobre seu papel no mundo não de forma individualizada, mas como parte de uma comunidade historicamente excluída, a protagonista demonstra as consequências sociais e psicológicas desta exclusão, demonstrando modos de viver diferenciados.

\section{REFERÊNCIAS}

ALVES, Miriam. A literatura negra feminina no Brasil - pensando a existência. Revista da ABPN. v. 1, n. 3, p. 181-189, novembro/fevereiro de 2010/2011. Disponível em: http://www.abpnrevista.org.br/revista/ index.php/revistaabpn1/article/view/280. Acesso em: 5 maio 2019. CHEVALIER, Jean; GHEERBRANT, Alain. Dicionário de símbolos. Rio de Janeiro: José Olympio, 2012. 
DUARTE, Eduardo de Assis. O Bildungsroman afro-brasileiro de Conceição Evaristo. Estudos Feministas, Florianópolis, n. 14, p. 305-308, 2006. Disponível em: http://www.scielo.br/pdf/ref/v14n1/a17v14n1.pdf. Acesso em: 15 dez. 2018.

EVARISTO, Conceição. Ponciá Vicêncio. Belo Horizonte: Mazza edições, 2003.

HALL, Stuart. Da diáspora: identidades e mediações culturais. Belo Horizonte, UFMG, 2018.

HUTCHEON, Linda. Poética do pós-modernismo: história, teoria, ficção. Rio de janeiro: Imago, 1991.

LE GOFF, Jacques. História e memória. Campinas: Unicamp, 1992.

MAAS, Wilma Patrícia Marzardi Dinardo. O cânone mínimo: o Bildungsroman na história da literatura. São Paulo: Editora Unesp, 2000. SALGUEIRO, Maria Aparecida Andrade. Escritoras negras contemporâneas. Estudos de narrativas - Estados Unidos e Brasil. Rio de Janeiro: Caetés, 2004.

TAVARES, Julio César. Diáspora africana: a experiência negra de interculturalidade. Cadernos Penesb. Periódico do Programa de Educação sobre o Negrona Sociedade Brasileira - FEUFF. Rio de Janeiro/ Niterói - EdUFF, n. 10, p. 77-85, 2008-2010.

\section{Angélica Maria Santana Batista}

Doutora em Literatura Comparada e mestre em Literatura Portuguesa pela Universidade do Estado do Rio de Janeiro (UERJ).

Participa do diretório de grupo de pesquisa do CNPq “Estudos Literários: outras linguagens; outros discursos.

Atua como educadora social em ONGs e eventos envolvendo a exaltação da literatura. Lattes: http://lattes.cnpq.br/9858240966265330 Email: angelicamsbatista@gmail.com 